\title{
Synthesis of (-)-Bulgecinine and 5-epi-Bulgecinine through Proline-Catalysed Asymmetric $\alpha$-Hydroxylation of an Aldehyde Derived from L-Glutamic Acid
}

\section{Vipin Kumar Jain* \\ Mrityunjay Kumar}

Department of Chemistry, Indian Institute of Technology Kanpur, Kanpur-208016, India jain91vipin@gmail.com

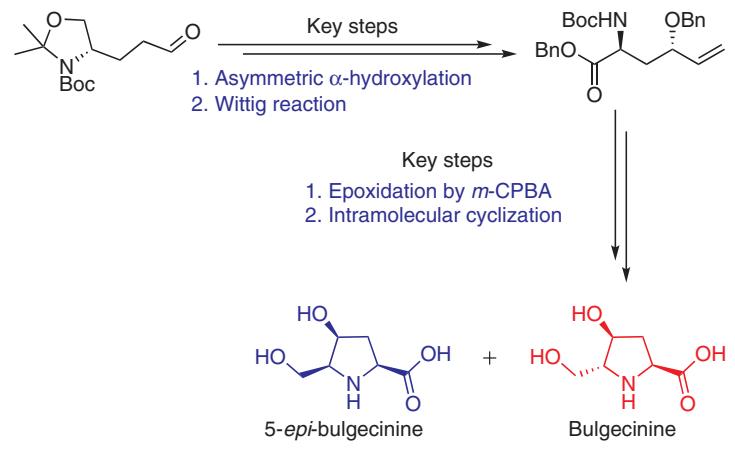

structure of bulgecinine can be considered as a derivative of proline, having an additional hydroxy and hydroxymethylene substituents at positions 4 and 5 of the pyrrolidine ring, respectively, and it is designated as $(2 S, 4 S, 5 R)-4$-hydroxy-5-hydroxymethyl proline. ${ }^{4}$ The structures of bulgecin $\mathrm{C}$ and $(+)$ - and (-)-bulgecinine are shown in Figure 1.

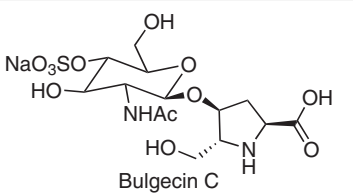

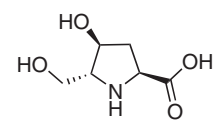

(-)-Bulgecinine

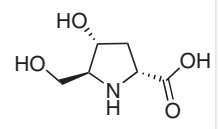

(+)-Bulgecinine
Figure 1 droxyl group at the $\alpha$-position to that aldehyde in good yield and with very high diastereoselectivity. Both (-)-bulgecinine and 5-epi-bulgecinine are synthesised from the same olefin via epoxidation followed by $\mathrm{BF}_{3} \cdot \mathrm{OEt}_{2}$-catalyzed intramolecular cyclisation. This synthetic route can easily be extended for the synthesis of the enantiomer and other isomers of bulgecinine starting from an aldehyde derived from D-glutamic acid.

Key words asymmetric hydroxylation, organocatalysis, diastereoselectivity, glycopeptide, antibiotics

(-)-Bulgecinine is a nonproteinogenic amino acid that is a constituent of naturally occurring antibiotic glycopeptides known as the bulgecins; it was first isolated from Pseudomonas acidophila and Pseudomonas mesoacidophila. ${ }^{1,2}$ Although the bulgecins by themselves show very little antibiotic activity, in combination with $\beta$-lactam antibiotics, their antibacterial activities against various Gram-negative microorganisms are greatly enhanced., ${ }^{3,4}$ When bulgecins interact with two penicillin-binding proteins, PBP-2 and PBP-3, they induce bulge formation in the cell wall of Gram-negative bacteria in association with $\beta$-lactam antibiotics. The bulge formation is responsible for efficient killing of bacteria even at low concentrations of antibiotics. The
Given its biological activities ${ }^{5-7}$ and structural aspects, various total syntheses of bulgecinine have been reported over the last two decades. ${ }^{8-18}$ In spite of these methods being available, the development of a new synthetic approach is always valid in terms of the use of readily available starting materials and the possibility of preparing structurally diverse analogues. We report here an alternative method to effectively synthesise (-)-bulgecinine and 5-epi-(-)-bulgecinine from an aldehyde derived from L-glutamic acid using proline-catalysed asymmetric $\alpha$-hydroxylation and $\mathrm{BF}_{3} \cdot \mathrm{OEt}_{2}$-mediated intramolecular epoxide ring opening with an amine as the key steps.

Proline-catalysed asymmetric $\alpha$-hydroxylation of an aldehyde using nitrosobenzene followed by reduction of the $\mathrm{N}-\mathrm{O}$ bond is an attractive method to incorporate a hydroxyl group stereoselectively. ${ }^{19,20}$ To avoid racemisation of the $\alpha$ centre, the aldehyde function is generally reduced to an alcohol prior to the reductive cleavage of the $\mathrm{N}-\mathrm{O}$ bond. As part of our ongoing interest in the synthesis of various bioactive and natural occurring molecules, ${ }^{21,22}$ we recently reported a successful application of this reaction to synthe- 
sise D-threo-sphinganine, L-erythro-sphinganine and (-)spisulosine from a higher homologue of Garner's aldehyde. $^{22}$

Our strategy towards the synthesis of $\mathbf{1}$ and $\mathbf{2}$ is based on the use of aldehyde $\mathbf{3}$, which was derived from L-glutamic acid (Scheme 1). This could be readily converted into compound $\mathbf{9}$ in six steps using proline-catalysed asymmetric $\alpha$-hydroxylation and a Wittig reaction as the key steps. Epoxidation using $m$-CPBA and intramolecular epoxide ring opening with an amine in the presence of $\mathrm{BF}_{3} \cdot \mathrm{OEt}_{2}$ would yield compounds $\mathbf{1}$ and 2, as shown in Scheme 1.

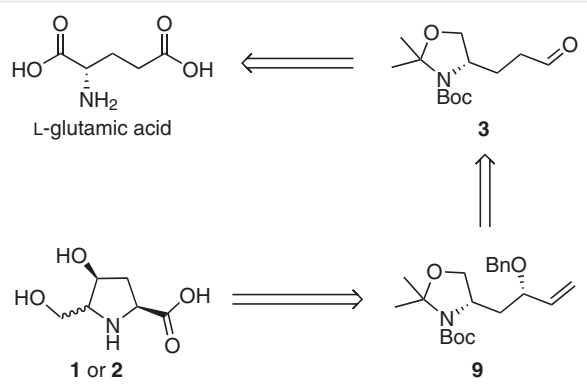

Scheme 1 Retrosynthesis of compounds $\mathbf{1}$ and $\mathbf{2}$ from $\mathbf{3}$

The required starting material $\mathbf{3}$ is commercially available or can be readily synthesised from L-glutamic acid. ${ }^{23-25}$ Aldehyde 3 was then subjected to diastereoselective $\alpha$-hydroxylation using nitrosobenzene, and D-proline as catalyst and the product was subsequently reduced to the corresponding primary alcohol with $\mathrm{NaBH}_{4}$ in one pot. The crude product was further subjected to $\mathrm{N}-\mathrm{O}$ bond cleavage using $\mathrm{Cu}(\mathrm{OAc})_{2}$ to obtain the diol 4 in $72 \%$ overall yield. It was determined by HPLC analysis that the $\alpha$-hydroxylation reac- tion proceed with very high diastereoselectivity $(\mathrm{dr}=92: 8)$. The primary hydroxyl group in $\mathbf{4}$ was protected as a TBDPS ether to furnish 5, which was then treated with benzyl bromide and $\mathrm{NaH}$ in the presence of tetrabutylammonium iodide (TBAI) to produce the fully protected compound $\mathbf{6}$ in $70 \%$ overall yield. The silyl protecting group in compound $\mathbf{6}$ was then selectively removed using tetrabutylammonium fluoride (TBAF) to give the corresponding primary alcohol 7 in $85 \%$ yield. Alcohol 7 was then oxidised to aldehyde 8 with 2 -iodoxybenzoic acid (IBX) in 90\% yield, and Wittig reaction of aldehyde $\mathbf{8}$ with methyltriphenylphosphonium bromide in the presence of $t$-BuOK yielded olefin $\mathbf{9}$ in $85 \%$ yield. The oxazolidine ring in compound $\mathbf{9}$ was deprotected using a catalytic amount of $p$-TsOH to result in amino alcohol $\mathbf{1 0}$ in $80 \%$ yield, as shown in Scheme 2.

Pyridinium dichromate (PDC) in DMF was used to oxidise the primary alcohol in $\mathbf{1 0}$ to carboxylic acid, followed by esterification with benzyl bromide in the presence of $\mathrm{K}_{2}$ $\mathrm{CO}_{3}$ as base to give $\mathbf{1 1}$ in $70 \%$ overall yield (Scheme 3). Epoxidation of olefin 11 using $m$-CPBA gave a mixture of epoxides 12 (86\%) in equal amounts (as judged by ${ }^{1} \mathrm{H}$ NMR spectroscopic analysis), which were not separable by using column chromatography. The mixture of diastereomeric epoxides was thus further subjected to $\mathrm{BF}_{3} \cdot \mathrm{OEt}_{2}$-catalysed intramolecular epoxide ring opening with the $\mathrm{N}$-Boc amino group to furnish pyrrolidines 13a and 13b, each in $47 \%$ yield after separation by column chromatography. Subsequent transformations were independently carried out in each series. Hydrogenolysis of both the benzyl groups using $\mathrm{Pd} / \mathrm{C}$ under hydrogen and deprotection of the Boc group using TFA furnished the target molecules 5-epi-(-)-bulgecinine (1) and (-)-bulgecinine (2) from 13a and 13b, respectively, in $84 \%$ overall yield (Scheme 3 ).
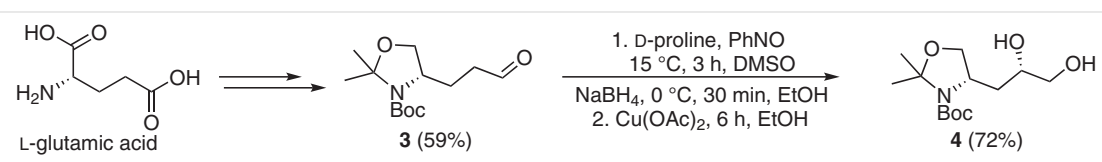

$$
\begin{array}{r}
\text { TBDPS-Cl, Et }{ }_{3} \mathrm{~N}, \text { DMAP } \\
0^{\circ} \mathrm{C}-\mathrm{rt}, 8 \mathrm{~h}, \mathrm{DCM}
\end{array}
$$

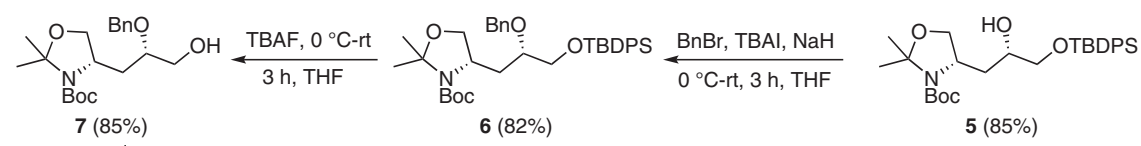

$\downarrow$ IBX, 3 h, DMSO
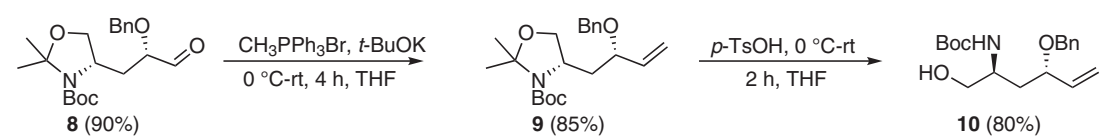

Scheme 2 Synthesis of compound $\mathbf{1 0}$ from aldehyde 3 


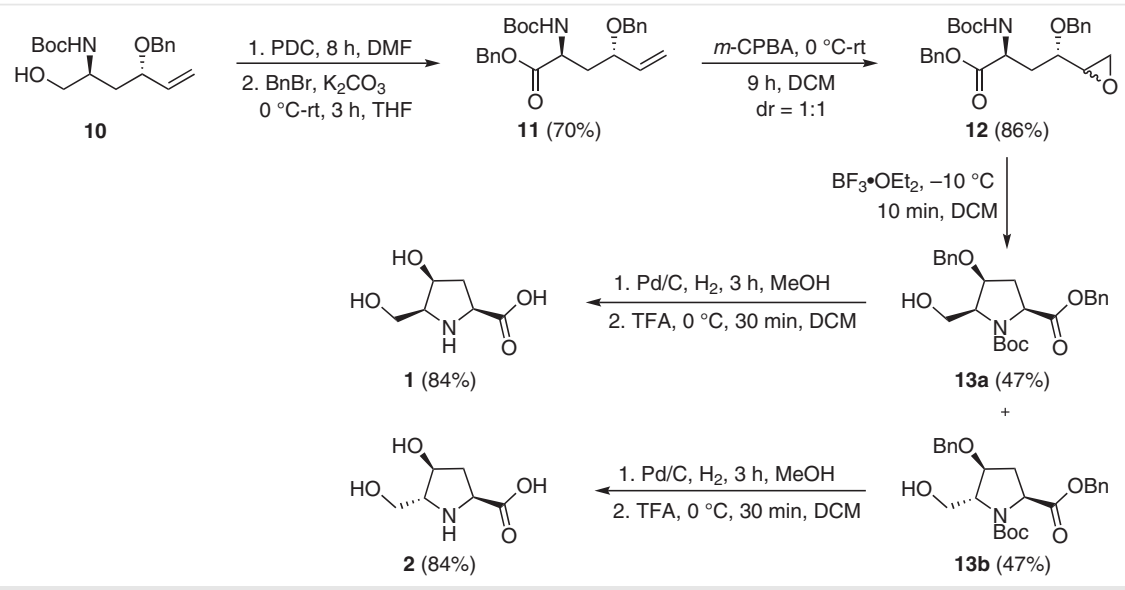

Scheme 3 Synthesis of 5-epi-bulgecinine (1) and bulgecine (2)

In conclusion, an efficient synthetic route to (-)-bulgecinine and 5-epi-(-)-bulgecinine from an aldehyde derived from L-glutamic acid is reported. Proline-catalysed asymmetric $\alpha$-hydroxylation of an aldehyde is the key step in this synthesis, being used to incorporate a hydroxyl group at the $\alpha$-position of the aldehyde in good yield and with very high diastereoselectivity. All the reactions were straightforward, high yielding and proceeded under mild conditions. Both (-)-bulgecinine and 5-epi-(-)-bulgecinine were synthesised from the same olefin via epoxidation followed by $\mathrm{BF}_{3} \cdot \mathrm{OEt}_{2}$ mediated intramolecular epoxide ring opening with an amine. This synthetic route can be readily extended to the synthesis of (+)-bulgecinine and its isomers starting from the corresponding aldehyde derived from Dglutamic acid.

All commercially available reagents were used directly without any further purification. All reactions were carried out in anhydrous solvents and under an inert atmosphere unless otherwise mentioned. Yields are reported for compounds purified by using column chromatography. All the reactions were monitored by analytical thin-layer chromatography carried out on $0.25 \mathrm{~mm}$ Merck silica gel plates (60F254) using UV light as a visualising agent and ninhydrin, $5 \% \mathrm{H}_{2} \mathrm{SO}_{4}$ as a staining agent. Column chromatography was performed using Merck silica gel (particle size 60-120 and 100-200 mesh) and appropriate mixtures of petroleum ether and EtOAc were used as eluent. ${ }^{1} \mathrm{H}$ NMR spectra were recorded at 400 or $500 \mathrm{MHz}$, using Jeol spectrometers; ${ }^{13} \mathrm{C}$ NMR spectra were recorded at 100 or $125 \mathrm{MHz}$. Chemical shifts are reported in parts per million (ppm) and coupling constants in hertz (Hz). ${ }^{1} \mathrm{H}$ NMR splitting patterns are designated as singlet (s), doublet (d), doublet of doublets (dd), triplet (t), multiplet (m), and broad singlet (bs). IR spectra were recorded as thin films for liquids and as $\mathrm{KBr}$ pellets for solids. High-resolution mass spectra were recorded with a Waters Q/Tof Premier micromass HAB 213 spectrometer with an ESI source. Specific rotations were measured using a 6.0 $\mathrm{mL}$ cell with a $10 \mathrm{dm}$ path length and are reported as $[\alpha]_{D}{ }^{25}$. The diastereoselectivity of the $\alpha$-hydroxylation step was determined by HPLC using an OD-H column and eluting with 6\% isopropanol and hexane with a $0.5 \mathrm{~mL} \mathrm{~min}^{-1}$ flow rate.

\section{Procedure for Asymmetric $\alpha$-Hydroxylation of Aldehyde 3}

To a stirred solution of the aldehyde $3(1.00 \mathrm{~g}, 3.88 \mathrm{mmol})$ and nitrosobenzene $(0.45 \mathrm{~g}, 4.27 \mathrm{mmol})$ in anhydrous DMSO $(10 \mathrm{~mL})$, D-proline $(0.13 \mathrm{~g}, 1.16 \mathrm{mmol}, 30 \mathrm{~mol} \%)$ was added at $15^{\circ} \mathrm{C}$. The mixture was stirred vigorously until the colour changed from deep green to orange-red (ca. $3 \mathrm{~h}$ ). The reaction mixture was brought to $0{ }^{\circ} \mathrm{C}$ and $\mathrm{NaBH}_{4}(0.17 \mathrm{~g}, 4.65 \mathrm{mmol})$ in EtOH $(15 \mathrm{~mL})$ was added to the cooled solution and the mixture was stirred vigorously for $30 \mathrm{~min}$. After completion of the reaction as observed by TLC, the reaction was quenched with saturated aqueous $\mathrm{NH}_{4} \mathrm{Cl}(30 \mathrm{~mL})$ and was extracted with EtOAc $(2 \times 30 \mathrm{~mL})$. The combined organic phases were washed with brine $(30 \mathrm{~mL})$, dried over $\mathrm{Na}_{2} \mathrm{SO}_{4}$, filtered, and concentrated.

The crude product was taken to the next step, leading to the cleavage of the $\mathrm{O}-\mathrm{N}$ bond. $\mathrm{Cu}(\mathrm{OAc})_{2}(0.18 \mathrm{~g}, 1.00 \mathrm{mmol})$ was added to a stirred solution of the above product $(1.23 \mathrm{~g}, 3.35 \mathrm{mmol})$ in $\mathrm{EtOH}(15 \mathrm{~mL})$ and the reaction was monitored using TLC. After completion of the reaction (ca. $6 \mathrm{~h}$ ), the reaction was quenched with saturated aqueous $\mathrm{NH}_{4} \mathrm{Cl}(20 \mathrm{~mL})$ and extracted with EtOAc $(2 \times 20 \mathrm{~mL})$. The combined organic phases were washed with brine $(30 \mathrm{~mL})$, dried over $\mathrm{Na}_{2} \mathrm{SO}_{4}$, filtered, concentrated, and purified by column chromatography.

\section{tert-Butyl-(S)-4-((S)-2,3-Dihydroxypropyl)-2,2-dimethyloxazoli-} dine-3-carboxylate (4)

Column chromatography (60:40, petroleum ether/EtOAc).

Yield: $0.77 \mathrm{~g}(72 \%)$; colourless oil; $[\alpha]_{\mathrm{D}}{ }^{27}-10.50$ (c $\left.0.20, \mathrm{CHCl}_{3}\right)$.

IR (Thin film): 3406, 2978, 1696, $1668 \mathrm{~cm}^{-1}$.

${ }^{1} \mathrm{H} \mathrm{NMR}\left(\mathrm{CDCl}_{3}, 500 \mathrm{MHz}\right): \delta=4.25-4.21(\mathrm{~m}, 1 \mathrm{H}), 4.02-3.99(\mathrm{~m}, 1 \mathrm{H})$, 3.67-3.56 (m, $3 \mathrm{H}), 3.50-3.46$ (m, $1 \mathrm{H}), 1.70-1.53$ (m, $2 \mathrm{H}), 1.50,1.49$ (s, $15 \mathrm{H})$.

${ }^{13} \mathrm{C} \mathrm{NMR}\left(\mathrm{CDCl}_{3}, 100 \mathrm{MHz}\right): \delta=154.3,93.9,81.4,68.5,68.4,66.5,54.1$, 39.1, 28.4, 28.0, 24.4 .

HRMS (ESI-TOF): $m / z[\mathrm{M}+\mathrm{Na}]^{+}$calcd for $\mathrm{C}_{13} \mathrm{H}_{25} \mathrm{NNaO}_{5}: 298.1630$; found: 298.1632 .

\section{Procedure for 0 -TBDPS Protection}

Compound 4 ( $1.00 \mathrm{~g}, 3.63 \mathrm{mmol}$ ) was dissolved in anhydrous $\mathrm{CH}_{2} \mathrm{Cl}_{2}$ $(20 \mathrm{~mL})$, the solution was cooled to $0{ }^{\circ} \mathrm{C}$ and triethylamine $(1.01 \mathrm{~mL}$, $7.26 \mathrm{mmol}$ ) added slowly. TBDPSCl (1.09 $\mathrm{mL}, 3.99 \mathrm{mmol})$ and DMAP ( $0.08 \mathrm{~g}, 0.72 \mathrm{mmol})$ were added to the above solution and the mixture was stirred well at r.t. for $8 \mathrm{~h}$. After completion of the reaction as ob- 
served by TLC, the reaction was quenched with saturated aqueous citric acid $(20 \mathrm{~mL})$, extracted with $\mathrm{CH}_{2} \mathrm{Cl}_{2}(2 \times 30 \mathrm{~mL})$ and the combined organic phases were dried over $\mathrm{Na}_{2} \mathrm{SO}_{4}$, filtered, concentrated, and purified by column chromatography.

\section{tert-Butyl (S)-4-((S)-3-((tert-Butyldiphenylsilyl)oxy)-2-hydroxy- propyl)-2,2-dimethyloxazolidine-3-carboxylate (5)}

Column chromatography (80:20, petroleum ether/EtOAc).

Yield: $1.58 \mathrm{~g}$ (85\%); colourless oil; $[\alpha]_{\mathrm{D}}{ }^{27}+5.81$ (c $\left.0.53, \mathrm{CHCl}_{3}\right)$.

IR (thin film): 3442, 2932, 2859, 1696, 1668, $1473 \mathrm{~cm}^{-1}$.

${ }^{1} \mathrm{H} \mathrm{NMR}\left(\mathrm{CDCl}_{3}, 400 \mathrm{MHz}\right): \delta=7.67-7.65(\mathrm{~m}, 4 \mathrm{H}), 7.42-7.35(\mathrm{~m}, 6 \mathrm{H})$, 4.19-4.15 (m, $1 \mathrm{H}), 4.01-3.93(\mathrm{~m}, 1 \mathrm{H}), 3.79-3.69(\mathrm{~m}, 3 \mathrm{H}), 3.61-3.58$ (m, $1 \mathrm{H}), 1.98-1.92(\mathrm{~m}, 1 \mathrm{H}), 1.68-1.65(\mathrm{~m}, 1 \mathrm{H}), 1.54,1.49(\mathrm{~s}, 15 \mathrm{H})$, $1.06(\mathrm{~s}, 9 \mathrm{H})$.

${ }^{13} \mathrm{C} \mathrm{NMR}\left(\mathrm{CDCl}_{3}, 100 \mathrm{MHz}\right): \delta=153.7,135.7,133.6,129.7,127.8,93.5$, 80.9, 69.1, 68.4, 67.8, 54.8, 38.9, 28.5, 27.8, 26.9, 24.6, 19.3.

HRMS (ESI-TOF): $m / z[\mathrm{M}+\mathrm{Na}]^{+}$calcd for $\mathrm{C}_{29} \mathrm{H}_{43} \mathrm{NNaO}_{5} \mathrm{Si}$ : 536.2808; found: 536.2802 .

\section{Procedure for $\boldsymbol{O}$-Benzyl Protection}

Silyl protected alcohol 5 ( $1.00 \mathrm{~g}, 1.94 \mathrm{mmol})$ was dissolved in a twoneck round-bottom flask under nitrogen in anhydrous THF $(10 \mathrm{~mL})$ and benzyl bromide $(0.27 \mathrm{~mL}, 2.32 \mathrm{mmol})$ and TBAI $(0.21 \mathrm{~g}, 0.58$ mmol) were added to the solution. The solution was cooled to $0{ }^{\circ} \mathrm{C}$ and $\mathrm{NaH}(0.10 \mathrm{~g}, 2.53 \mathrm{mmol})$ was added and the mixture was stirred at r.t. for $3 \mathrm{~h}$. After completion of the reaction as observed by TLC, the reaction was quenched with saturated aqueous $\mathrm{NH}_{4} \mathrm{Cl}(20 \mathrm{~mL})$, extracted with EtOAc $(2 \times 30 \mathrm{~mL})$ and the combined organic phases were dried over $\mathrm{Na}_{2} \mathrm{SO}_{4}$, filtered, concentrated, and purified by column chromatography.

tert-Butyl-(S)-4-((S)-2-(Benzyloxy)-3-((tert-butyldiphenylsilyl)oxy)propyl)-2,2-dimethyloxazolidine-3-carboxylate (6) Column chromatography (90:10, petroleum ether/EtOAc). Yield: $0.96 \mathrm{~g}(82 \%)$; colourless oil; $[\alpha]_{\mathrm{D}}{ }^{27}-4.39$ (c $\left.0.52, \mathrm{CHCl}_{3}\right)$. IR (thin film): 3393, 2932, 2859, 1696, $1454 \mathrm{~cm}^{-1}$.

${ }^{1} \mathrm{H}$ NMR $\left(\mathrm{CDCl}_{3}, 400 \mathrm{MHz}\right): \delta=7.69-7.65(\mathrm{~m}, 4 \mathrm{H}), 7.41-7.25(\mathrm{~m}$, $11 \mathrm{H}), 4.68(\mathrm{~d}, J=12.0 \mathrm{~Hz}, 1 \mathrm{H}), 4.48(\mathrm{~d}, J=12.0 \mathrm{~Hz}, 1 \mathrm{H}), 3.90-3.36(\mathrm{~m}$, $6 \mathrm{H}), 2.04-1.71(\mathrm{~m}, 2 \mathrm{H}), 1.54-1.37(\mathrm{~m}, 15 \mathrm{H}), 1.06,1.03(\mathrm{~s}, 9 \mathrm{H})$.

${ }^{13} \mathrm{C}$ NMR $\left(\mathrm{CDCl}_{3}, 100 \mathrm{MHz}\right): \delta=152.3,151.6,138.9,138.6,136.0$, 135.9, 135.7, 133.4, 129.8, 128.4, 127.8, 93.4, 92.9, 80.0, 79.5, 79.0, $72.5,72.2,68.5,66.9,66.6,56.5,56.3,36.7,35.9,29.8,28.5,27.7,26.9$, 24.7, 23.3, 19.3 .

HRMS (ESI-TOF): $m / z$ [M + H] $]^{+}$calcd for $\mathrm{C}_{36} \mathrm{H}_{50} \mathrm{NO}_{5} \mathrm{Si}: 604.3458$; found: 604.3456 .

\section{Procedure for 0-TBDPS Deprotection}

Tetrabutyl ammonium fluoride ( $1 \mathrm{M}$ in THF, $1.98 \mathrm{~mL}, 1.98 \mathrm{mmol}$ ) was added to a stirred solution of compound $6(1.00 \mathrm{~g}, 1.65 \mathrm{mmol})$ in anhydrous THF $(15 \mathrm{~mL})$ at $0{ }^{\circ} \mathrm{C}$ and the mixture stirred at r.t. for $3 \mathrm{~h}$. After completion of the reaction as observed by TLC, the reaction was quenched with saturated aqueous $\mathrm{NH}_{4} \mathrm{Cl}(30 \mathrm{~mL})$, extracted with EtOAc $(2 \times 30 \mathrm{~mL})$ and the combined organic phases were dried over $\mathrm{Na}_{2} \mathrm{SO}_{4}$, filtered, concentrated, and purified by column chromatography.
tert-Butyl (S)-4-((S)-2-(Benzyloxy)-3-hydroxypropyl)-2,2-dimethyloxazolidine-3-carboxylate (7)

Column chromatography (70:30, petroleum ether/EtOAc). Yield: $0.51 \mathrm{~g}$ (85\%); colourless oil; $[\alpha]_{D}{ }^{27}+10.61$ (c 0.93, $\mathrm{CHCl}_{3}$ ). IR (thin film): 3446, 2977, 2932, 2871, 1696, 1669, $1454 \mathrm{~cm}^{-1}$. ${ }^{1} \mathrm{H} \mathrm{NMR}\left(\mathrm{CDCl}_{3}, 400 \mathrm{MHz}\right): \delta=7.32-7.25(\mathrm{~m}, 5 \mathrm{H}), 4.65-4.51(\mathrm{~m}, 2 \mathrm{H})$, 4.44 (bs, $1 \mathrm{H}), 4.21-4.16(\mathrm{~m}, 1 \mathrm{H}), 3.99-3.70(\mathrm{~m}, 3 \mathrm{H}), 3.46-3.44(\mathrm{~m}$, $2 \mathrm{H}), 1.84-1.78(\mathrm{~m}, 1 \mathrm{H}), 1.62-1.55(\mathrm{~m}, 1 \mathrm{H}), 1.52(\mathrm{~s}, 3 \mathrm{H}), 1.47(\mathrm{~s}$, $12 \mathrm{H})$.

${ }^{13} \mathrm{C} \mathrm{NMR}\left(\mathrm{CDCl}_{3}, 100 \mathrm{MHz}\right): \delta=153.9,138.3,128.4,127.8,127.6,93.7$, 81.0, 74.2, 73.4, 68.4, 67.4, 66.6, 60.7, 56.7, 54.5, 39.4, 29.7, 28.4, 27.9, 24.5.

HRMS (ESI-TOF): $m / z[\mathrm{M}+\mathrm{Na}]^{+}$calcd for $\mathrm{C}_{20} \mathrm{H}_{31} \mathrm{NNaO}_{5}: 388.2100$; found: 388.2101 .

\section{Procedure for Primary Alcohol Oxidation}

IBX $(0.91 \mathrm{~g}, 3.28 \mathrm{mmol})$ was added to a solution of $7(1.00 \mathrm{~g}, 2.73$ $\mathrm{mmol})$ in DMSO $(10 \mathrm{~mL})$ and the mixture stirred at r.t. for $3 \mathrm{~h}$. After the completion of the reaction as observed by TLC, the reaction was quenched with saturated aqueous $\mathrm{NaHCO}_{3}(50 \mathrm{~mL})$, extracted with EtOAc $(2 \times 30 \mathrm{~mL})$ and the combined organic phases were washed with brine $(30 \mathrm{~mL})$, dried over $\mathrm{Na}_{2} \mathrm{SO}_{4}$, filtered, concentrated, and purified by column chromatography.

\section{tert-Butyl (S)-4-((S)-2-(Benzyloxy)-3-oxopropyl)-2,2-dimethylox-} azolidine-3-carboxylate $(8)$

Column chromatography (80:20, petroleum ether/EtOAc).

Yield: $0.89 \mathrm{~g}$ (90\%); colourless oil; $[\alpha]_{\mathrm{D}}{ }^{27}-12.65$ (c $0.31, \mathrm{CHCl}_{3}$ ).

IR (thin film): 2924, 2854, 1734, 1696, $1455 \mathrm{~cm}^{-1}$.

${ }^{1} \mathrm{H} \mathrm{NMR}\left(\mathrm{CDCl}_{3}, 400 \mathrm{MHz}\right): \delta=9.61(\mathrm{~s}, 1 \mathrm{H}), 7.33(\mathrm{bs}, 5 \mathrm{H}), 4.67(\mathrm{~d}, J=$ $12.0 \mathrm{~Hz}, 1 \mathrm{H}), 4.52(\mathrm{~d}, J=12.0 \mathrm{~Hz}, 1 \mathrm{H}), 4.02-3.88(\mathrm{~m}, 3 \mathrm{H}), 3.74$ (bs, $1 \mathrm{H}), 2.19-1.75(\mathrm{~m}, 2 \mathrm{H}), 1.55,1.52(\mathrm{~s}, 3 \mathrm{H}), 1.47,1.42(\mathrm{~s}, 12 \mathrm{H})$.

${ }^{13} \mathrm{C} \mathrm{NMR}\left(\mathrm{CDCl}_{3}, 100 \mathrm{MHz}\right): \delta=202.4,152.5,137.3,128.7,128.3,93.7$, 93.3, 82.6, 80.4, 72.9, 68.1, 55.8, 33.5, 29.8, 28.5, 27.8, 24.6.

HRMS (ESI-TOF): $m / z$ [M $+\mathrm{H}]^{+}$calcd for $\mathrm{C}_{20} \mathrm{H}_{30} \mathrm{NO}_{5}$ : 364.2124; found: 364.2128 .

\section{Procedure for Wittig Reaction}

To a solution of methyl triphenyl phosphonium bromide (1.96 g, 5.50 $\mathrm{mmol})$, and $t$-BuOK $(0.58 \mathrm{~g}, 5.22 \mathrm{mmol})$ in anhydrous THF $(20 \mathrm{~mL})$, aldehyde $8(1.0 \mathrm{~g}, 2.75 \mathrm{mmol})$ was added slowly at $0{ }^{\circ} \mathrm{C}$ and the mixture stirred at r.t. for 4 hours. After completion of the reaction as observed by TLC, the reaction was quenched with saturated aqueous $\mathrm{NH}_{4} \mathrm{Cl}(30$ $\mathrm{mL})$ and extracted with EtOAc $(2 \times 30 \mathrm{~mL})$. The combined organic phases were dried over $\mathrm{Na}_{2} \mathrm{SO}_{4}$, filtered, concentrated, and purified by column chromatography.

tert-Butyl (S)-4-((S)-2-(Benzyloxy)but-3-en-1-yl)-2,2-dimethyloxazolidine-3-carboxylate $(9)$

Column chromatography (90:10, petroleum ether/EtOAc).

Yield: $0.84 \mathrm{~g}$ (85\%) colourless oil; $[\alpha]_{\mathrm{D}}{ }^{27}-12.58$ (c $\left.0.86, \mathrm{CHCl}_{3}\right)$.

IR (thin film): 2978, 2933, 2869, 1698, $1496 \mathrm{~cm}^{-1}$.

${ }^{1} \mathrm{H} \mathrm{NMR}\left(\mathrm{CDCl}_{3}, 400 \mathrm{MHz}\right): \delta=7.29-7.25(\mathrm{~m}, 5 \mathrm{H}), 5.74-5.72(\mathrm{~m}, 1 \mathrm{H})$, 5.27-5.18 (m, $2 \mathrm{H}), 4.57-4.48$ ( $\mathrm{m}, 1 \mathrm{H}$, ), 4.30-4.27 (m, $1 \mathrm{H}), 4.00-3.79$ (m, $3 \mathrm{H}), 3.71$ (bs, $1 \mathrm{H}), 2.03-1.80(\mathrm{~m}, 2 \mathrm{H}), 1.51,1.43(\mathrm{~s}, 15 \mathrm{H})$. 
${ }^{13} \mathrm{C}$ NMR $\left(\mathrm{CDCl}_{3}, 100 \mathrm{MHz}\right): \delta=152.1,151.6,138.5,128.4,127.7$, 127.6, 118.0, 117.6, 115.4, 93.4, 92.8, 80.1, 79.6, 70.1, 68.1, 56.5, 55.9, 39.7, 38.8, 28.5, 27.6, 26.8, 24.7, 23.4.

HRMS (ESI-TOF): $m / z$ [M $+\mathrm{H}]^{+}$calcd for $\mathrm{C}_{21} \mathrm{H}_{32} \mathrm{NO}_{4}$ : 362.2331 ; found: 362.2331 .

\section{Procedure for Oxazolidine Deprotection}

p-TsOH $(0.79 \mathrm{~g}, 4.15 \mathrm{mmol})$ was added to a stirred solution of compound $9(1.00 \mathrm{~g}, 2.76 \mathrm{mmol})$ in $\mathrm{MeOH}(20 \mathrm{~mL})$ at $0{ }^{\circ} \mathrm{C}$ and the mixture stirred at r.t. for $2 \mathrm{~h}$. After completion of the reaction as observed by $\mathrm{TLC}$, the reaction was quenched with saturated aqueous $\mathrm{NaHCO}_{3}(10$ $\mathrm{mL}$ ). The $\mathrm{MeOH}$ was removed under reduced pressure, the aqueous layer was extracted with EtOAc $(2 \times 20 \mathrm{~mL})$ and the combined organic phases were dried over $\mathrm{Na}_{2} \mathrm{SO}_{4}$, filtered, concentrated, and purified by column chromatography.

\section{tert-Butyl ((2S,4S)-4-(Benzyloxy)-1-hydroxyhex-5-en-2-yl)carba- mate (10)}

Column chromatography (70:30, petroleum ether/EtOAc).

Yield: $0.71 \mathrm{~g}$ (80\%); colourless oil; $[\alpha]_{\mathrm{D}}{ }^{27}-23.79$ (c $\left.0.93, \mathrm{CHCl}_{3}\right)$.

IR (thin film): 3407, 2976, 2929, 1690, $1499 \mathrm{~cm}^{-1}$.

${ }^{1} \mathrm{H} \mathrm{NMR}\left(\mathrm{CDCl}_{3}, 400 \mathrm{MHz}\right): \delta=7.33-7.25(\mathrm{~m}, 5 \mathrm{H}), 5.79-5.70(\mathrm{~m}, 1 \mathrm{H})$, $5.28-5.23(\mathrm{~m}, 3 \mathrm{H}), 4.55(\mathrm{~d}, J=12.0 \mathrm{~Hz}, 1 \mathrm{H}), 4.30(\mathrm{~d}, J=12.0 \mathrm{~Hz}, 1 \mathrm{H})$, 3.93-3.82 (m, 2 H), 3.59 (bs, 2 H,), 2.98 (bs, 1 H), 1.82-1.75 (m, 2 H), $1.42(\mathrm{~s}, 9 \mathrm{H})$

${ }^{13} \mathrm{C}$ NMR $\left(\mathrm{CDCl}_{3}, 100 \mathrm{MHz}\right): \delta=156.4,138.0,128.5,128.2,127.8$, $117.6,79.5,78.1,70.7,65.8,50.5,37.0,29.8,28.5$

HRMS (ESI-TOF): $m / z[\mathrm{M}+\mathrm{Na}]^{+}$calcd for $\mathrm{C}_{18} \mathrm{H}_{27} \mathrm{NNaO}_{4}: 344.1838$; found: 344.1830 .

\section{Procedure Primary Alcohol Oxidation}

Pyridinium dichromate $(11.71 \mathrm{~g}, 31.13 \mathrm{mmol})$ was added to a stirred solution of alcohol $10(1.00 \mathrm{~g}, 3.11 \mathrm{mmol})$ in DMF (30 mL) and the mixture was stirred at r.t. for $8 \mathrm{~h}$. After completion of the reaction as observed by TLC, the reaction was quenched with water $(300 \mathrm{~mL})$ and the mixture was extracted with EtOEt $(2 \times 50 \mathrm{~mL})$. The combined organic phases were further extracted with saturated aqueous $\mathrm{NaHCO}_{3}$ $(2 \times 30 \mathrm{~mL})$. The combined aqueous extracts containing the carboxylate salt were combined, acidified with saturated aqueous $\mathrm{KHSO}_{4}$ and extracted with $\mathrm{Et}_{2} \mathrm{O}(2 \times 50 \mathrm{~mL})$. The ether layers were combined, dried over $\mathrm{Na}_{2} \mathrm{SO}_{4}$, filtered, and concentrated under reduced pressure.

The crude product $(0.82 \mathrm{~g}, 2.44 \mathrm{mmol})$ was dissolved in anhydrous THF and the mixture was cooled to $0{ }^{\circ} \mathrm{C}$. Benzyl bromide $(0.37 \mathrm{~mL}$, $3.17 \mathrm{mmol})$ and $\mathrm{K}_{2} \mathrm{CO}_{3}(0.50 \mathrm{~g}, 3.66 \mathrm{mmol})$ were then added and the mixture was stirred at r.t. for $3 \mathrm{~h}$. After completion of the reaction as observed by TLC, the reaction was quenched with saturated aqueous $\mathrm{NH}_{4} \mathrm{Cl}(30 \mathrm{~mL})$ and extracted with EtOAc $(2 \times 30 \mathrm{~mL})$. The combined organic phases were dried over $\mathrm{Na}_{2} \mathrm{SO}_{4}$, filtered, concentrated, and purified by column chromatography.

\section{Benzyl (2S,4S)-4-(Benzyloxy)-2-((tert-butoxycarbonyl)amino)hex- 5-enoate (11)}

Column chromatography (90:10, petroleum ether/EtOAc).

Yield: $0.91 \mathrm{~g}$ (70\%); colourless oil; $[\alpha]_{\mathrm{D}}^{27}-4.65$ (c $0.73, \mathrm{CHCl}_{3}$ ).

IR (thin film): 3412, 2976, 1716, 1497, $1454 \mathrm{~cm}^{-1}$.
${ }^{1} \mathrm{H}$ NMR $\left(\mathrm{CDCl}_{3}, 400 \mathrm{MHz}\right): \delta=7.34-7.25(\mathrm{~m}, 10 \mathrm{H}), 5.73-5.63(\mathrm{~m}$, $2 \mathrm{H}), 5.24-5.04(\mathrm{~m}, 4 \mathrm{H}), 4.54-4.50(\mathrm{~m}, 1 \mathrm{H}), 4.44(\mathrm{~d}, J=12.0 \mathrm{~Hz}, 1 \mathrm{H})$, $4.19(\mathrm{~d}, J=12.0 \mathrm{~Hz}, 1 \mathrm{H}), 3.76-3.71(\mathrm{~m}, 1 \mathrm{H}), 2.08-1.91(\mathrm{~m}, 2 \mathrm{H}), 1.42$ (s, $9 \mathrm{H})$.

${ }^{13} \mathrm{C}$ NMR $\left(\mathrm{CDCl}_{3}, 100 \mathrm{MHz}\right): \delta=172.4,155.7,137.9,137.5,135.7$, $128.6,128.5,128.5,128.4,128.2,127.8,118.0,79.6,78.3,70.8,66.9$, 51.9, 37.3, 29.8, 28.4.

HRMS (ESI-TOF): $m / z[\mathrm{M}+\mathrm{Na}]^{+}$calcd for $\mathrm{C}_{25} \mathrm{H}_{31} \mathrm{NNaO}_{5}: 448.2100$; found: 448.2107 .

\section{Procedure for Alkene Epoxidation}

$m$-Chloroperbenzoic acid (50-55\%, $0.81 \mathrm{~g}, 4.70 \mathrm{mmol}$ ) was added to a stirred solution of alkene $\mathbf{1 1}(1.0 \mathrm{~g}, 2.35 \mathrm{mmol})$ in anhydrous $\mathrm{CH}_{2} \mathrm{Cl}_{2}$ $(20 \mathrm{~mL})$ at $0{ }^{\circ} \mathrm{C}$ and the mixture was stirred at r.t. for $9 \mathrm{~h}$. After completion of the reaction as observed by TLC, the reaction was quenched with saturated aqueous $\mathrm{Na}_{2} \mathrm{SO}_{3}(30 \mathrm{~mL})$ and the mixture was extracted with $\mathrm{CH}_{2} \mathrm{Cl}_{2}(2 \times 30 \mathrm{~mL})$. The combined organic phases were dried over $\mathrm{Na}_{2} \mathrm{SO}_{4}$, filtered, concentrated, and purified by column chromatography.

Benzyl (2S,4S)-4-(Benzyloxy)-2-((tert-butoxycarbonyl)amino)-4(oxiran-2-yl)butanoate (12)

Column chromatography (80:20, petroleum ether/EtOAc).

Yield: $0.89 \mathrm{~g}$ (86\%); colourless oil; $[\alpha]_{\mathrm{D}}{ }^{27}-5.78$ (c $\left.0.38, \mathrm{CHCl}_{3}\right)$.

IR (thin film): 3380, 2925, 2854, 1715, $1455 \mathrm{~cm}^{-1}$.

${ }^{1} \mathrm{H} \mathrm{NMR}\left(\mathrm{CDCl}_{3}, 400 \mathrm{MHz}\right): \delta=7.38-7.25(\mathrm{~m}, 10 \mathrm{H}), 5.59(\mathrm{~d}, J=8.0 \mathrm{~Hz}$, $1 \mathrm{H}), 5.46(\mathrm{~d}, J=8.0 \mathrm{~Hz}, 1 \mathrm{H}), 5.22-5.02(\mathrm{~m}, 2 \mathrm{H}), 4.77-4.36(\mathrm{~m}, 3 \mathrm{H})$, 3.25-2.83 (m, $2 \mathrm{H}), 2.75-2.59(\mathrm{~m}, 2 \mathrm{H}), 2.24-1.92(\mathrm{~m}, 3 \mathrm{H}), 1.41(\mathrm{~s}$, $9 \mathrm{H})$.

${ }^{13} \mathrm{C}$ NMR $\left(\mathrm{CDCl}_{3}, 100 \mathrm{MHz}\right): \delta=172.4,155.6,137.8,135.5,135.5$, 128.7, 128.6, 128.5, 128.5, 128.3, 128.0, 127.9, 79.7, 78.6, 76.0, 73.1, 72.5, 67.1, 54.5, 53.0, 51.5, 51.3, 46.0, 42.8, 34.7, 33.8, 29.8, 28.4.

HRMS (ESI-TOF): $m / z[\mathrm{M}+\mathrm{Na}]^{+}$calcd for $\mathrm{C}_{25} \mathrm{H}_{31} \mathrm{NNaO}_{6}: 464.2049$; found: 464.2041 .

Note: Additional peaks observed in the NMR spectra at r.t. are due to the existence of rotamers.

\section{Procedure for Epoxide Ring Opening Reaction}

$\mathrm{BF}_{3} \cdot \mathrm{OEt}_{2}$ ( $50 \%$ solution, $0.037 \mathrm{~mL}, 0.14 \mathrm{mmol}$ ) dissolved in anhydrous $\mathrm{CH}_{2} \mathrm{Cl}_{2}(0.50 \mathrm{~mL})$ was added to a stirred solution of compound $\mathbf{1 2}$ ( $0.13 \mathrm{~g}, 0.29 \mathrm{mmol})$ in anhydrous $\mathrm{CH}_{2} \mathrm{Cl}_{2}(6 \mathrm{~mL})$ at $-10{ }^{\circ} \mathrm{C}$ under nitrogen and reaction mixture was stirred for $10 \mathrm{~min}$ at the same temperature. After completion of the reaction as observed by TLC, the reaction was quenched with saturated aqueous $\mathrm{NaHCO}_{3}(10 \mathrm{~mL})$, extracted with $\mathrm{CH}_{2} \mathrm{Cl}_{2}(2 \times 20 \mathrm{~mL})$ and the combined organic phases were dried over $\mathrm{Na}_{2} \mathrm{SO}_{4}$, filtered, concentrated, and purified by column chromatography.

2-Benzyl 1-(tert-Butyl) (2S,4S,5S)-4-(Benzyloxy)-5-(hydroxymethyl)pyrrolidine-1,2-dicarboxylate (13a)

Column chromatography (60:40, petroleum ether/EtOAc). Yield: $0.06 \mathrm{~g}(47 \%)$ colourless oil; $[\alpha]_{\mathrm{D}}^{27}-25.01$ (c $\left.0.65, \mathrm{CHCl}_{3}\right)$. IR (thin film): 3455, 2931, 1754, 1699, 1497, $1454 \mathrm{~cm}^{-1}$.

${ }^{1} \mathrm{H}$ NMR $\left(\mathrm{CDCl}_{3}, 400 \mathrm{MHz}\right): \delta=7.28-7.25(\mathrm{~m}, 10 \mathrm{H}), 5.21-4.90(\mathrm{~m}$, $2 \mathrm{H}), 4.56-4.36(\mathrm{~m}, 3 \mathrm{H}), 4.16$ (bs, $1 \mathrm{H}), 4.05-3.84(\mathrm{~m}, 1 \mathrm{H}), 3.69$ (bs, $3 \mathrm{H}), 2.36-2.27$ (m, $2 \mathrm{H}), 1.43,1.32(\mathrm{~s}, 9 \mathrm{H})$. 
${ }^{13} \mathrm{C}$ NMR $\left(\mathrm{CDCl}_{3}, 100 \mathrm{MHz}\right): \delta=171.9,155.7,137.7,135.7,128.5$, 128.4, 128.3, 127.7, 127.6, 81.1, 79.4, 70.5, 66.9, 65.9, 64.4, 59.7, 34.9, 28.4, 28.2.

HRMS (ESI-TOF): $m / z[\mathrm{M}+\mathrm{Na}]^{+}$calcd for $\mathrm{C}_{25} \mathrm{H}_{31} \mathrm{NNaO}_{6}: 464.2049$; found: 464.2042 .

\section{2-Benzyl 1-(tert-Butyl) (2S,4S,5R)-4-(Benzyloxy)-5-(hydroxymeth-} yl)pyrrolidine-1,2-dicarboxylate (13b)

Column chromatography (60:40, petroleum ether/EtOAc).

Yield: $0.06 \mathrm{~g}$ (47\%); colourless oil; $[\alpha]_{D}{ }^{27}+11.18$ (c $0.42, \mathrm{CHCl}_{3}$ ).

IR (thin film): 3417, 2930, 1732, 1698, 1497, $1455 \mathrm{~cm}^{-1}$.

${ }^{1} \mathrm{H}$ NMR $\left(\mathrm{CDCl}_{3}, 400 \mathrm{MHz}\right): \delta=7.31-7.25(\mathrm{~m}, 10 \mathrm{H}), 5.26-5.05(\mathrm{~m}$, $2 \mathrm{H}), 4.58-4.41$ ( $\mathrm{m}, 2 \mathrm{H}), 4.30-4.27$ ( $\mathrm{m}, 1 \mathrm{H}), 4.18-3.87$ ( $\mathrm{m}, 5 \mathrm{H}), 2.51-$ $2.30(\mathrm{~m}, 1 \mathrm{H}), 2.22-2.01(\mathrm{~m}, 1 \mathrm{H}), 1.45,1.32(\mathrm{~s}, 9 \mathrm{H})$.

${ }^{13} \mathrm{C}$ NMR $\left(\mathrm{CDCl}_{3}, 100 \mathrm{MHz}\right): \delta=173.3,173.0,154.7,154.1,137.5$, 135.3, 128.7, 128.6, 128.4, 128.2, 128.0, 127.7, 81.1, 81.0, 72.1, 71.7, $67.2,62.0,60.8,60.0,57.7,56.7,34.1,33.3,29.8,28.4,28.2$.

HRMS (ESI-TOF): $m / z[\mathrm{M}+\mathrm{Na}]^{+}$calcd for $\mathrm{C}_{25} \mathrm{H}_{31} \mathrm{NNaO}_{6}: 464.2049$; found: 464.2043.

\section{General Procedure for Hydrogenolysis and $\boldsymbol{N}$-Boc Deprotection}

To a stirred solution of compound $13(0.06 \mathrm{~g}, 0.13 \mathrm{mmol})$ in $\mathrm{MeOH}$ $(10 \mathrm{~mL}), 10 \mathrm{~mol} \%, \mathrm{Pd} / \mathrm{C}(10 \%)$ was added and the mixture was stirred at r.t. for $3 \mathrm{~h}$ under $\mathrm{H}_{2}$. After completion of the reaction as observed by TLC, the reaction mixture was filtered through a Celite ${ }^{\circledR}$ pad and solvent was removed under reduced pressure.

TFA $(0.50 \mathrm{~mL})$ was added to a stirred solution of the crude product obtained after hydrogenolysis in anhydrous $\mathrm{CH}_{2} \mathrm{Cl}_{2}(2 \mathrm{~mL})$ at $0{ }^{\circ} \mathrm{C}$ and the solution was stirred until completion of reaction as observed by TLC. The reaction mixture was concentrated under reduced pressure and the residue was dissolved in $\mathrm{CH}_{2} \mathrm{Cl}_{2}(10 \mathrm{~mL})$ and concentrated again. This was repeated four times to remove TFA and other volatile material completely from the crude product.

\section{(2S,4S,5S)-4-Hydroxy-5-(hydroxymethyl)pyrrolidine-2-carboxylic} Acid (1)

Yield: $0.03 \mathrm{~g}$ (84\%); colourless oil; $[\alpha]_{\mathrm{D}}{ }^{27}-10.50$ (c $\left.0.50, \mathrm{CH}_{3} \mathrm{OH}\right)$.

IR (thin film): 2955, 2923, 2852, $1647 \mathrm{~cm}^{-1}$.

${ }^{1} \mathrm{H}$ NMR $\left(\mathrm{D}_{2} \mathrm{O}, 400 \mathrm{MHz}\right): \delta=4.54(\mathrm{bs}, 1 \mathrm{H}), 4.42(\mathrm{dd}, J=6.5,5.0 \mathrm{~Hz}$, $1 \mathrm{H}), 4.08-3.93(\mathrm{~m}, 2 \mathrm{H}), 3.75-3.72(\mathrm{~m}, 1 \mathrm{H}), 2.64-2.57(\mathrm{~m}, 1 \mathrm{H}), 2.35$ (dd, $J=6.5,5.0 \mathrm{~Hz}, 1 \mathrm{H}$ ).

${ }^{13} \mathrm{C}$ NMR $\left(\mathrm{D}_{2} \mathrm{O}, 100 \mathrm{MHz}\right): \delta=69.4,65.8,58.6,57.4,37.2$.

HRMS (ESI-TOF): $m / z[\mathrm{M}+\mathrm{H}]^{+}$calcd for $\mathrm{C}_{6} \mathrm{H}_{12} \mathrm{NO}_{4}$ : 162.0766 ; found: 162.0764 .

\section{(2S,4S,5R)-4-Hydroxy-5-(hydroxymethyl)-pyrrolidine-2-carboxyl-} ic Acid (2)

Yield: $0.03 \mathrm{~g}$ (84\%); colourless oil; $[\alpha]_{\mathrm{D}}{ }^{27}-13.10\left(\mathrm{c} 0.50, \mathrm{CH}_{3} \mathrm{OH}\right)\left\{\right.$ Lit. $^{15}$ $[\alpha]_{D}^{23}-13.8$ (c $\left.\left.0.21, \mathrm{H}_{2} \mathrm{O}\right)\right\}$.

IR (thin film): 3392, 2917, 2850, $1648 \mathrm{~cm}^{-1}$.

${ }^{1} \mathrm{H}$ NMR $\left(\mathrm{D}_{2} \mathrm{O}, 500 \mathrm{MHz}\right): \delta=4.43(\mathrm{q}, J=5.0 \mathrm{~Hz}, 1 \mathrm{H}), 4.27(\mathrm{dd}, J=9.0$, $6.5 \mathrm{~Hz}, 1 \mathrm{H}), 3.95(\mathrm{dd}, J=15.0,5.0 \mathrm{~Hz}, 1 \mathrm{H}), 3.80-3.78(\mathrm{~m}, 2 \mathrm{H}), 2.72$ (ddd, $J=13.8,9.0,6.8 \mathrm{~Hz}, 1 \mathrm{H}$ ), 2.21 (ddd, $J=13.8,6.5,5.0 \mathrm{~Hz}, 1 \mathrm{H}$ ).

${ }^{13} \mathrm{C}$ NMR $\left(\mathrm{D}_{2} \mathrm{O}, 125 \mathrm{MHz}\right): \delta=70.3,66.7,59.1,57.8,36.3$.

HRMS (ESI-TOF): $m / z[\mathrm{M}+\mathrm{H}]^{+}$calcd for $\mathrm{C}_{6} \mathrm{H}_{12} \mathrm{NO}_{4}$ : 162.0766; found: 162.0782 .

\section{Funding Information}

V.K.J. thanks CSIR - Indian Institute of Chemical Biology $\square$ mok? $\square$ for a Senior Research Fellowship

\section{Acknowledgment}

V.K.J. thanks Dr. Ramesh Ramapanicker for assistance and provision of facilities, and I.I.T. Kanpur for provision of instrumentation.

\section{Supporting Information}

Supporting information for this article is available online at https://doi.org/10.1055/s-0039-1690332.

\section{References and notes}

(1) Shinagawa, S.; Maki, M.; Kintaka, K.; Imada, A.; Asai, M. J. Antibiot. 1985, 38, 17.

(2) Imada, A.; Kintaka, K.; Nakao, M.; Shinagawa, S. J. Antibiot. 1982, $35,1400$.

(3) Kraft, A. R.; Prabhu, J.; Ursinus, A.; Holtje, J. V. J. Bacteriol. 1999, $181,7192$.

(4) Shinagawa, S.; Kashara, F.; Wada, Y.; Harada, S.; Asai, M. Tetrahedron 1984, 40, 3465.

(5) Van Asselt, E. J.; Kalk, K. H.; Dijkstra, B. W. Biochemistry 2000 , 39, 1924.

(6) Thunnissen, A. M. W. H.; Rozeboom, H. J.; Kalk, K. H.; Dijkstra, B. W. Biochemistry 1995, 34, 12729.

(7) Templin, M. F.; Edwards, D. H.; Hoeltje, J. Y. J. Biol. Chem. 1992 267, 20039; and references therein

(8) Das, B.; Kumar, D. N. Synlett 2011, 1285.

(9) Show, K.; Upadhyay, P. K.; Kumar, P. Tetrahedron: Asymmetry 2011, 22, 1234.

(10) Toumi, M.; Couty, F.; Evano, G. Tetrahedron Lett. 2008, 49, 1175.

(11) Krasinski, A.; Jurczak, J. Tetrahedron Lett. 2001, 42, 2019.

(12) Holt, K. A.; Swift, J. P.; Smith, M. E. B.; Taylor, S. J. C.; McCague, R. Tetrahedron Lett. 2002, 43, 1545.

(13) Khalaf, J. K.; Dutta, A. J. Org. Chem. 2004, 69, 387.

(14) Chavan, S. P.; Praveen, C.; Sharma, P.; Kalkote, U. R. Tetrahedron Lett. 2005, 46, 439.

(15) Trost, B. M.; Horne, D. B.; Woltering, M. J. Chem. Eur. J. 2006, 12, 6607.

(16) Chandrasekhar, S.; Chandrashekar, G.; Vijeendera, K.; Sarma, G. D. Tetrahedron: Asymmetry 2006, 17, 2864.

(17) Wang, J.-T.; Lin, T.-C.; Chen, Y.-H.; Lin, C.-H.; Fang, J.-M. MedChemComm 2013, 4, 783 .

(18) Natori, Y.; Kikuchi, S.; Kondo, T.; Saito, Y.; Yoshimura, Y.; Takahata, H. Org. Biomol. Chem. 2014, 12, 1983.

(19) (a) Venkataramasubramanian, V.; Chaithanya Kiran, I. N.; Sudalai, A. Synlett 2015, 26, 355. (b) Kumar, P.; Dwivedi, N. Acc. Chem. Res. 2013, 46, 289. (c) Zhong, G. Angew. Chem. Int. Ed. 2003, 42, 4247. (d) Mukherjee, S.; Yang, J. W.; Hoffmann, S.; List, B. Chem. Rev. 2007, 107, 5471. (e) Vilaivan, T.; Bhanthumnavin, W. Molecules 2010, 15, 917. (f) Lalwani, K. G.; Sudalai, A. Synlett 2016, 27, 1339. (g) Hayashi, Y.; Yamaguchi, J.; Hibino, K.; Shoji, M. Tetrahedron Lett. 2003, 44, 8293. (h) Mangion, I. K.; MacMillan, D. W. C. J. Am. Chem. Soc. 2005, 127, 3696. (i) Momiyama, N.; Yamamoto, H. J. Am. Chem. Soc. 2003, 125, 6038. (j) Lee, L. G.; Whitesides, G. M. J. Org. Chem. 1986, 51, 25. 
(k) Chacko, S.; Ramapanicker, R. J. Org. Chem. 2015, 80, 4776. (l) Brown, S. P.; Brochu, M. P.; Sinz, C. J.; MacMillan, D. W. C. J. Am. Chem. Soc. 2003, 125, 10808.

(20) Janey, J. M. Angew. Chem. Int. Ed. 2005, 44, 4292.

(21) Petakamsetty, R.; Jain, V. K.; Majhi, P. K.; Ramapanicker, R. Org. Biomol. Chem. 2015, 13, 8512.
(22) Jain, V. K.; Ramapanicker, R. Tetrahedron 2017, 73, 1568.

(23) Petakamsetty, R.; Das, R. P.; Ramapanicker, R. Tetrahedron 2014, $70,9554$.

(24) Truchot, C.; Wang, Q.; Sasaki, N. A. Eur. J. Org. Chem. 2005, 1765.

(25) Xu, Z.; Zhang, F.; Zhang, L.; Jia, Y. Org. Biomol. Chem. 2011, 9, 2512. 